\title{
Effect of Dispersion Treatment on Dairy Waste Activated Sludge to Hasten the Production of Biogas
}

\author{
D. P. Rufus ${ }^{1}$, J. Rajesh Banu ${ }^{2 *}$, R. Yukesh Kannah ${ }^{2}$, Dinh Duc Nguyen ${ }^{3,4}$, \\ Gopalakrishnan Kumar ${ }^{5}$, Soon Woong Chang ${ }^{4}$ and S. Antony Raja ${ }^{1 *}$
}

${ }^{1}$ Department of Mechanical Engineering, Karunya Institute of Technology and Sciences, Coimbatore, India, ${ }^{2}$ Department of Civil Engineering, Anna University Regional Campus Tirunelveli, Tirunelveli, India, ${ }^{3}$ Institute of Research and Development, Duy Tan University, Da Nang, Vietnam, ${ }^{4}$ Department of Environmental Energy Engineering, Kyonggi University, Suwon, South Korea, ${ }^{5}$ Faculty of Science and Technology, Institute of Chemistry, Bioscience, and Environmental Engineering, University of Stavanger, Stavanger, Norway

\section{OPEN ACCESS}

Edited by:

Abdul-Sattar Nizami,

King Abdulaziz University, Saudi Arabia

Reviewed by:

Leandro Cardoso de Morais, São Paulo State University, Brazil

Qaisar Mahmood,

COMSATS University, Islamabad

Campus, Pakistan

*Correspondence:

S. Antony Raja

santonyraja@karunya.edu

J. Rajesh Banu

rajeshces@gmail.com

Specialty section:

This article was submitted to

Bioenergy and Biofuels,

a section of the journal

Frontiers in Energy Research

Received: 09 August 2019 Accepted: 11 November 2019 Published: 12 December 2019

Citation:

Rufus DP, Banu JR, Kannah RY, Nguyen DD, Kumar G, Chang SW and Raja SA (2019) Effect of Dispersion Treatment on Dairy Waste Activated Sludge to Hasten the Production of

Biogas. Front. Energy Res. 7:136 doi: 10.3389/fenrg.2019.00136
The solubilization potential of biological pre-treatment for waste activated sludge (WAS) is limited due to the floc structure of the WAS. Extra polymeric substances (EPS) are responsible for floc formation. In this investigation, an attempt has been made to disturb the floc structure of WAS by removing EPS with a disperser. In the first stage, the disperser treatment released $242 \mathrm{mg} / \mathrm{L}$ of soluble EPS when operated at 3,000 rpm for a duration of $50 \mathrm{~s}$ and caused deflocculation of WAS. In the second stage, deflocculated sludge was subjected to bacterial pre-treatment to assess the effect of floc disruption. During bacterial pre-treatment, it was found that deflocculated sludge produced higher organic solubilization of $23.9 \%$ and a reduction in suspended solids of $19.1 \%$ when compared to control (10.2 and $8.7 \%$, respectively). Biogas yields were recorded of $220 \mathrm{~mL} / \mathrm{g}$ COD in deflocculated sludge and $93 \mathrm{~mL} / \mathrm{g}$ COD in flocculated sludge. From the above, it is evident that deflocculation effectively enhanced bacterial pre-treatment, leading to more solubilization and biogas production.

Keywords: deflocculation, anaerobic biodegradability, disperser treatment, cell disintegration, biogas

\section{INTRODUCTION}

Currently, there is a high demand for energy to satisfy the day-to-day requirements of society. Obtaining this energy from waste is one prime option for meeting the energy demand. Among the different types of wastes, the waste activated sludge (WAS) generated from aerobic wastewater treatment plants has great potential for generating energy, as it has an $\sim 70 \%$ organic content (Kannah et al., 2019a). WAS typically contains an abundance of organics, principally protein and carbohydrate, and also a certain amount of complex organic polymers (Saha et al., 2011). In addition, the management of WAS in treatment plants (stabilization, thickening, dewatering, and disposal) accounts for nearly $60 \%$ of the total operational cost. It is thus advantageous to generate energy from WAS, as this will not only reduce the total operational cost of the treatment but also generate energy (methane). The additional energy can be used to compensate for a certain portion of the total input energy to a wastewater treatment plant (Kannah et al., 2019b). Industries conventionally employ aerobic treatment systems to treat their wastewater. Dairy is one such industry where aerobic treatment systems are extensively used. Since the biodegradability of dairy wastewater is high and it is laden with a significant amount of organics, it generates a huge amount of waste activated sludge. Therefore, in this study, an attempt has been made to make use of this 
sludge to solve the energy crisis. In India, the dairy industry is maintaining $15 \%$ compounded annual growth and plays a vital role in the economy.

Energy in the form of methane can be generated from waste biomass through anaerobic digestion. The efficiency of anaerobic digestion depends upon substrate complexity (Kavitha et al., 2019a). The anaerobic biodegradability of complex substrates can be enhanced through solubilization (Banu and Kavitha, 2017; Banu et al., 2017). WAS is a complex substrate, and its anaerobic biodegradability can be increased by enhancing its solubilization through pre-treatment methods (Yang et al., 2013). There are numerous pre-treatments available in the literature to solubilize WAS (Banu et al., 2012; Devi et al., 2014; Kannah et al., 2017a; Kavitha et al., 2019b). By carefully observing the above-mentioned disintegration process, the thermal process has been proved to be efficient (Jang and Ahn, 2013). In thermal treatment, heating is achieved via convection, which demands a huge amount of electrical energy. This makes the process economically infeasible. In addition, temperaturebased pre-treatment methods are known for their generation of recalcitrant compounds. These compounds inhibit substrate anaerobic biodegradability (Banu et al., 2019a; Jeong et al., 2019). Of late, a microwave disintegration process has been developed to decompose waste into distinct particles. Although biomass solubilization is high in ozone, microwave, and ultrasonic pretreatment, these pre-treatment methods are not widely used as they demand a large amount of energy. Bacterial pre-treatment can be an alternative to these methods, as it consumes less energy (Kavitha et al., 2015a). It is reported in the literature that a minimum of $20 \%$ cell disintegration is essential for economical biogas production (Ebenezer et al., 2015; Banu et al., 2019b). The limitation of bacterial pre-treatment is that it fails to achieve this landmark 20\% COD solubilization in WAS. This could be due to the structural integrity of WAS, which hides biomass from being exposed to the extracellular enzymes secreted by bacterial pre-treatment agents. In the present study, an attempt has been made to achieve this landmark 20\% COD solubilization by disrupting the structural integrity of sludge flocs. This was achieved by a disperser that works on the principle of a pressure gradient and shear stress (Devi et al., 2014; Kavitha et al., 2016a). When WAS is subjected to disperser pre-treatment at low rpm, extracellular polymeric substance (EPS), which is responsible for floc formation in WAS (Yu et al., 2010), is removed. After attaining deflocculation, it is subjected to bacterial pre-treatment. The key goals of the present investigation are to (1) disturb the structural integrity of WAS through deflocculation by a disperser, (2) use bacterially mediated disintegration of deflocculated sludge to achieve $20 \%$ solubilization, and (3) evaluate the efficiency of deflocculation.

\section{MATERIALS AND METHODS}

\section{Characteristics of Waste Activated Sludge (WAS)}

The WAS from the return line of an activated sludge treatment plant was collected from the Aavin dairy wastewater treatment
TABLE 1 | Initial characteristics of WAS.

\begin{tabular}{lc}
\hline Initial characteristics of WAS & Value \\
\hline $\mathrm{pH}$ & 6.91 \\
Total solids (TS) & $12,560 \pm 740 \mathrm{mg} / \mathrm{L}$ \\
Suspended solids (SS) & $7,000 \pm 230 \mathrm{mg} / \mathrm{L}$ \\
Total chemical oxygen demand (TCOD) & $10,000 \pm 720 \mathrm{mg} / \mathrm{L}$ \\
Soluble chemical oxygen demand (SCOD) & $400 \pm 56 \mathrm{mg} / \mathrm{L}$ \\
Volatile solids (VS) & $5,600 \pm 580 \mathrm{mg} / \mathrm{L}$ \\
Protein & $72.6 \pm 6.3 \mathrm{mg} / \mathrm{L}$ \\
Carbohydrate & $6.1 \pm 1.1 \mathrm{mg} / \mathrm{L}$ \\
\hline
\end{tabular}

plant located in the Madurai region, India. As soon as the sludge had been transported to the laboratory, it was stored at $4^{\circ} \mathrm{C}$. The initial characteristics of the WAS are tabulated in Table $\mathbf{1}$.

\section{Deflocculation of WAS}

A mechanical disperser (Make: IKA; Model No. T25 Ultra Turrax) was used to deflocculate the waste activated sludge. Defloculation experiments were carried out in a $1 \mathrm{~L}$ beaker containing $500 \mathrm{~mL}$ of WAS. The experiments were conducted at various disperser rpm values from 1,000 to 5,000. During the study, samples were periodically collected and examined for protein, carbohydrate, DNA, and soluble EPS to optimize the operational conditions of the disperser for deflocculation.

\section{Bacterial Pre-treatment of WAS}

The bacterial strain used in this study was an exoenzymesecreting strain, Bacillus licheniformis (genome accession number CP000002). Bacterial pre-treatment experiments were carried out in a $250 \mathrm{~mL}$ conical flask in a sterile environment. In the first set, $100 \mathrm{~mL}$ of deflocculated waste activated sludge (EPS removed) was inoculated with $2.0 \mathrm{~g} / \mathrm{L}$ of bacteria. In the second set, flocculated waste activated sludge (EPS intact) was inoculated with $2.0 \mathrm{~g} / \mathrm{L}$ of bacteria. The third set served as a control and contained only $100 \mathrm{~mL}$ of flocculated waste activated sludge. After inoculation, conical flasks were transferred to a low-speed stirrer and rotated at $100 \mathrm{rpm}$ for $84 \mathrm{~h}$.

\section{Biochemical Methane Potential Test (BMP)}

BMP was carried out as detailed in earlier studies (Uma Rani et al., 2014). Conventionally, researchers employ BMP as a tool to evaluate the efficiency of a pre-treatment method. BMP was carried out for bacterially pre-treated flocculated (EPS intact) and deflocculated (EPS removed) sludge samples. Raw sludge (untreated) was used as a control. BMP experiments were conducted in a $300-\mathrm{mL}$ serum bottle. It is essential to neutralize the substrate $\mathrm{pH}$ before BMP, as pre-treatment decreases the $\mathrm{pH}$ of the medium. After adding substrate into the BMP bottles, it was inoculated with bovine rumen, with a substrate to inoculum ratio of $3: 1$. After inoculation, the head space of the BMP bottles was flushed with nitrogen, and the bottles were sealed immediately to ensure anaerobic conditions. A needle was inserted into the top of the sealed bottle to measure biogas production. The entire setup was kept at $35^{\circ} \mathrm{C}$ and shaken at 220 
$\mathrm{rpm}$ in an incubator shaker. As the experiment proceeded, biogas generation occurred in the BMP bottles and created pressure, leading to displacement of the syringe piston. The distance traveled by the syringe piston was recorded and tabulated every day. The methane content of the biogas was measured using GC (Banu et al., 2019b). The BMP experiments were carried out for 25 days based on the findings of Gayathri et al. (2015). The modified Gompertz equation was employed in the study to validate the result.

$$
B_{t}=B \times \exp \left[-\exp \left[\frac{R_{b}}{B} \times \exp (\lambda-t)+1\right]\right]
$$

Where,

$\mathrm{B}_{\mathrm{t}}$ - Cumulative biogas produced $(\mathrm{mL})$ at time $(\mathrm{t})$,

$\mathrm{B}$ - Biogas production potential L/(g VS),

$\mathrm{R}_{\mathrm{b}}$ - Maximum biogas production rate $\mathrm{L} /(\mathrm{g} \mathrm{VS} \mathrm{d}$ ),

$\lambda$ - Lag phase (minimum period to produce methane).

\section{Analytical Method}

SS (suspended solids), TCOD (total chemical oxygen demand), and SCOD (soluble chemical oxygen demand) were measured according to predefined standard methods (APHA, 2005). The level of protein was computed by employing Lowry's method (Takahashi et al., 2010). Carbohydrate was examined via the anthrone-sulphuric acid method (Kavitha et al., 2015b), DNA was quantified with the diphenylamine calorimetric method (Merrylin et al., 2013), and EPS was calculated by following the procedure detailed in Kavitha et al. (2013).

\section{RESULTS AND DISCUSSION \\ Deflocculation of WAS Using Dispersion Treatment}

During dispersion, the sludge particles are broken down with mechanical energy, leading to deflocculation of WAS. Deflocculation depends on EPS removal. During deflocculation, flocs release extra-cellular organic compounds, such as protein, carbohydrate, and DNA. These contribute a meager increase in the concentration of soluble organics in the medium. It is also reported in the literature that dispersers induce cell disintegration. During cell disintegration, the cell wall of the biomass is cleaved, and this results in the leakage of organic-rich

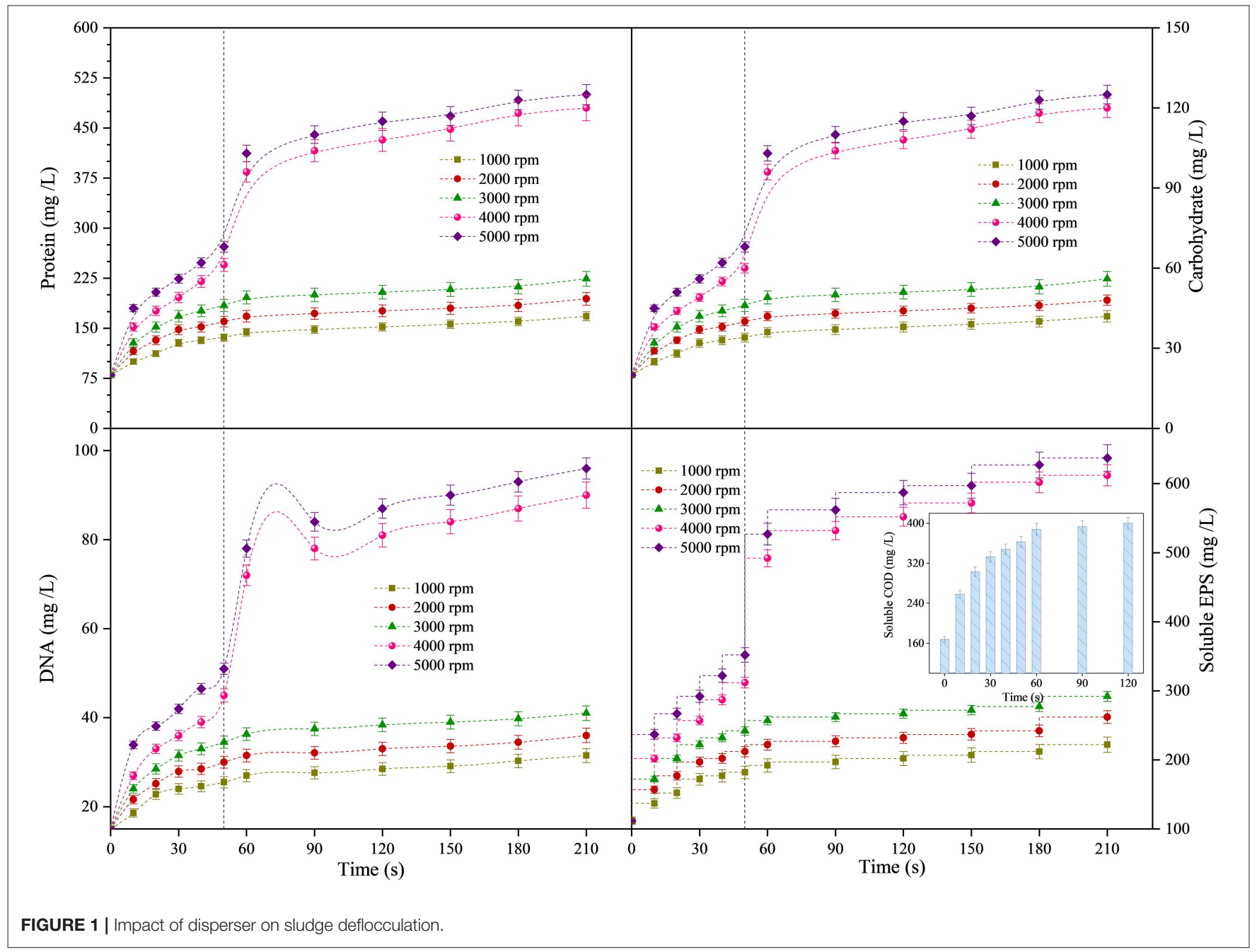


intracellular compounds into the medium. A sharp increase in medium soluble COD indicates the process of cell disintegration. Among the rpm rates used, a disperser rpm of up to 3,000 did not induce a sharp increase in medium organics (Figure 1). Up to
3,000 rpm, the disperser released a marginal amount of organics. There was no significant release in organics after $50 \mathrm{~s}$ (Figure 1), indicating saturation of deflocculation. Hence, $50 \mathrm{~s}$ of disperser operation at 3,000 rpm is found to be an effective condition for

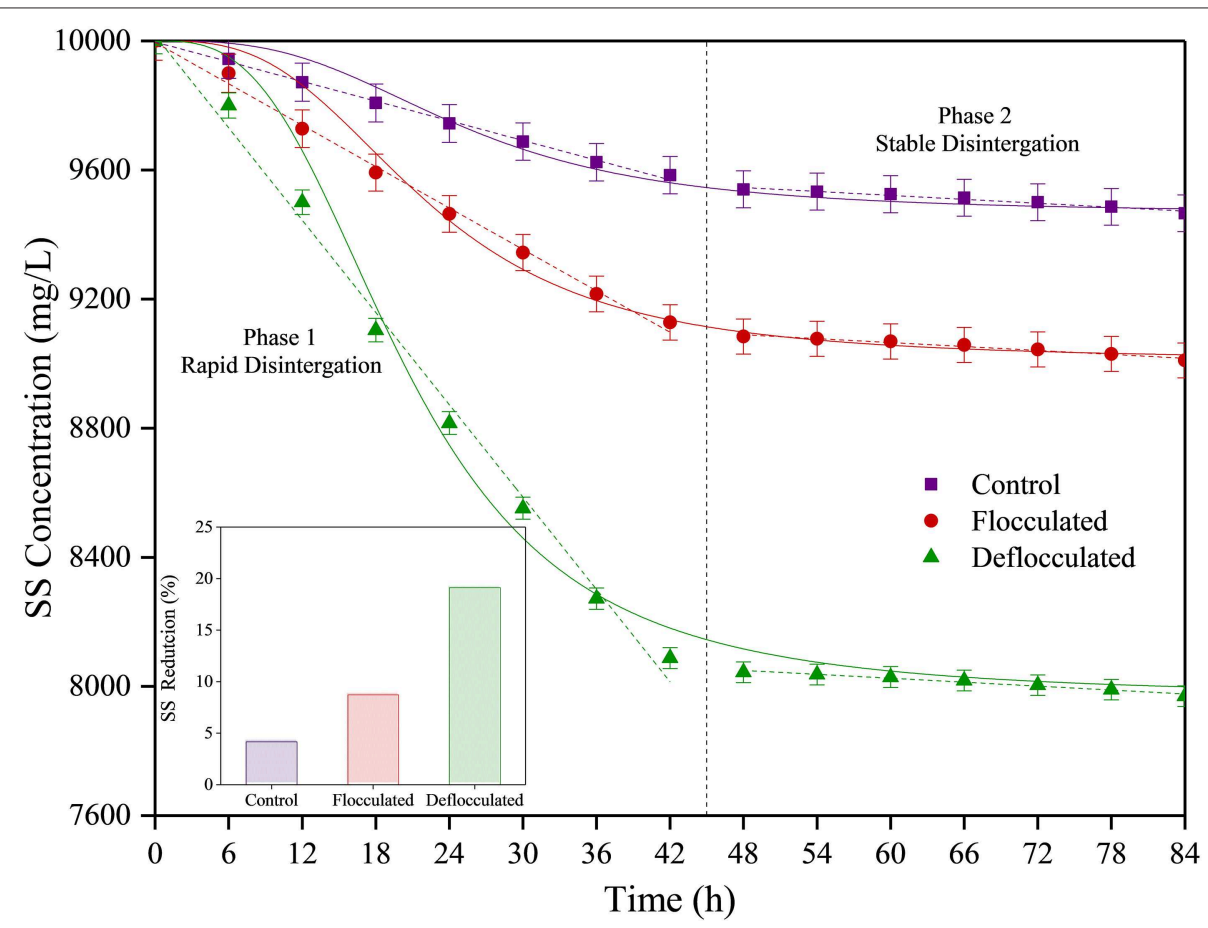

FIGURE 2 | Effect of bacterial disintegration on SS reduction.

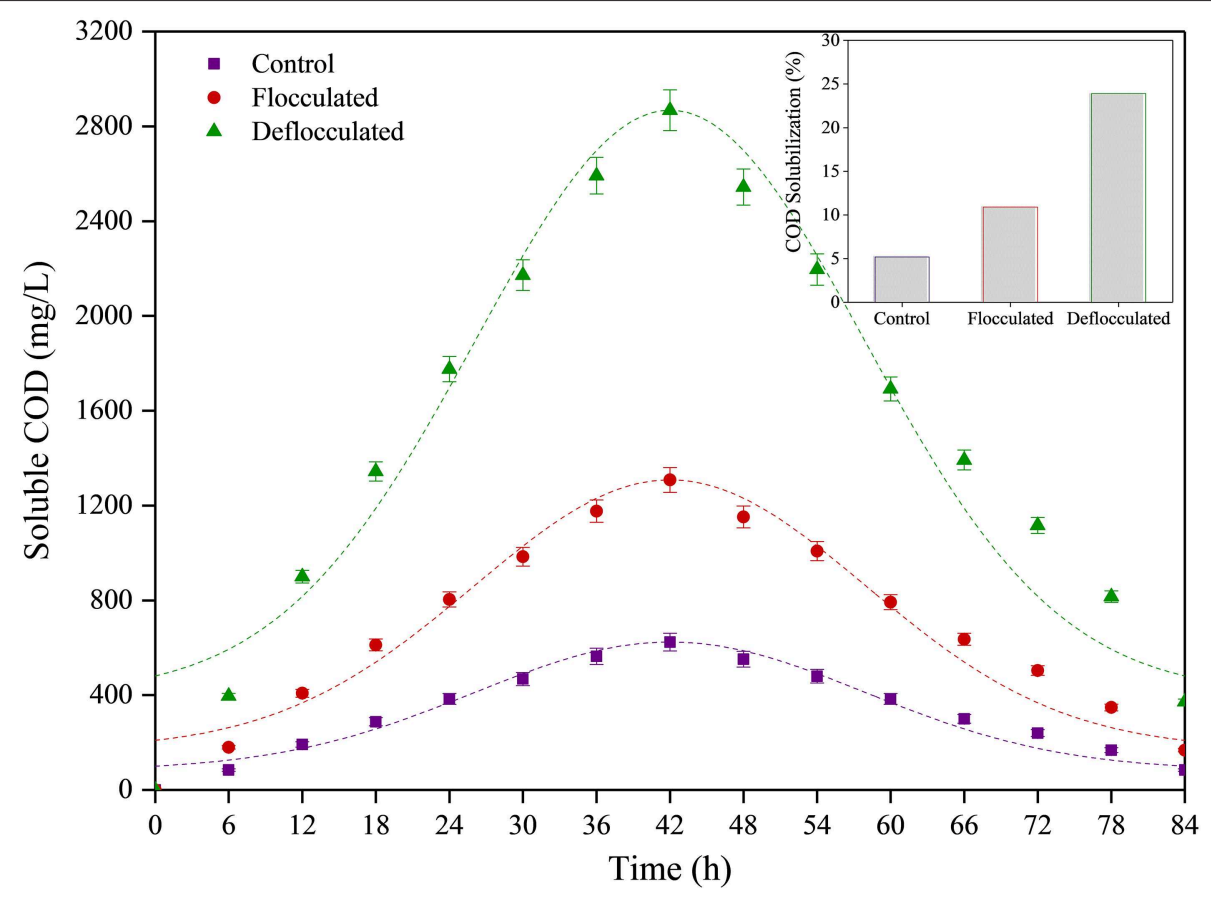

FIGURE 3 | Effect of bacterial disintegration on soluble COD release. 
deflocculating the sludge. At 3,000 rpm, $184 \mathrm{mg} / \mathrm{L}$ of protein and $46 \mathrm{mg} / \mathrm{L}$ of carbohydrate were released at $50 \mathrm{~s}$. Likewise, 242 $\mathrm{mg} / \mathrm{L}$ of soluble EPS and $363 \mathrm{mg} / \mathrm{L}$ soluble COD release were recorded. The released protein and carbohydrates are from the EPS, which is responsible for floc formation in waste activated sludge. Upon the action of the disperser, these components are released from EPS, resulting in floc disintegration. Beyond $50 \mathrm{~s}$ of dispersion, the release of organic compounds into the medium becomes saturated. The protein, carbohydrate, soluble EPS, and DNA release were found to be 196, 49, 257, and $36.3 \mathrm{mg} / \mathrm{L}$, respectively. The disperser works on the principle of rotor-stator theory. Mechanical shear force is generated due to high rotational speed and minimal space between the rotor and stator, which effectively deflocculates the sludge matrix (Devi et al., 2014; Kavitha et al., 2014a, 2016b; Kannah et al., 2017b). Increasing the rotational speed resulted in a rapid increment in biopolymer release, which indicates the disintegration phase. A sharp increase in DNA can be used as an indicator of the shift in paradigms from deflocculation to disintegration (Gayathri et al., 2015). Hence, it is obligatory to take a sample before the disintegration stage for better phase separation. At 4,000 and 5,000 rpm, the disperser causes a sharp increment in DNA, which indicates that disintegration is in progress. Hence, for deflocculation, a higher disperser rpm cannot be used. Based on the results, the optimum conditions to deflocculate waste activated sludge were found to be $3,000 \mathrm{rpm}$ and $50 \mathrm{~s}$. A similar phenomenon during the deflocculation of WAS was previously reported in Packyam et al. (2015). Biomass contains a significant amount of intracellular biopolymers. Kavitha et al. (2018) have used proteins and carbohydrates as markers to phase-separate deflocculation and disintegration. Any abrupt change in the release of biopolymers can be taken as an indicator for phase separation. As expected, an abrupt increase in the release of protein $(384,412 \mathrm{mg} / \mathrm{L})$ was noticed at 4,000 and 5,000 rpm, as depicted in Figure 1. Similarly, there was a leap in carbohydrate release $(96 \mathrm{mg} / \mathrm{L}, 103 \mathrm{mg} / \mathrm{L})$ at speeds of 4,000 and 5,000 rpm, again depicted in Figure 1. From the above, it was clear that cell disintegration was prominent when the rpm value of the disperser was increased above 3,000 rpm. Hence, it is clear that phase separation cannot be achieved in a disperser when its rpm is increased in excess of 3,000. At 3,000 rpm, phase separation was prominent, and the results of Figure 1 show a clear demarcation at $50 \mathrm{~s}$.

\section{Bacterial Disintegration of WAS}

Biological disintegration is the most widely used method of biomass disintegration. However, its application in real time is limited due to its inability to induce solubilization of over $20 \%$. In this study, an attempt has been made to achieve this with a biological pre-treatment experiment in the absence of EPS. During the experiment, performance parameters of disintegration, such as COD, protein, and carbohydrate release, were used to assess the difference between flocculated and deflocculated sludge samples. The

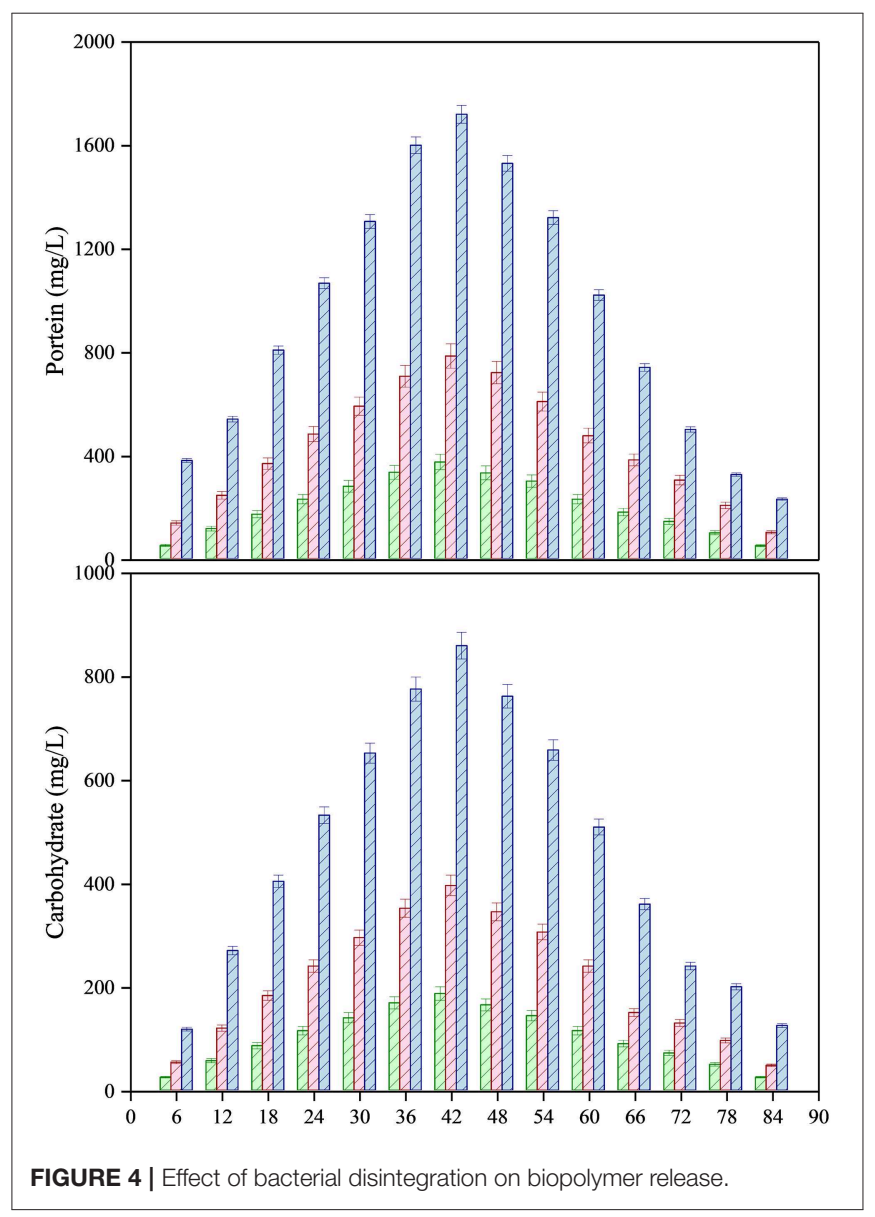

TABLE 2 | Comparison of COD solubilization and SS reduction with various phase-separated bacterial pre-treatments.

\begin{tabular}{|c|c|c|c|c|}
\hline S. No. & Pre-treatment & COD solubilization (\%) & SS reduction $(\%)$ & References \\
\hline 1. & Magnesium chloride-mediated bacterial pre-treatment & $21.4 \%$ & $22.4 \%$ & Kavitha et al., 2015a \\
\hline 2. & Calcium chloride-mediated bacterial pre-treatment & $17.14 \%$ & $14.14 \%$ & Kavitha et al., 2015c \\
\hline 3. & Titanium dioxide-mediated bacterial pre-treatment & $22.9 \%$ & $22.8 \%$ & Sharmila et al., 2015 \\
\hline 4. & Low-temperature thermochemically mediated bacterial pre-treatment & $17 \%$ & $17.2 \%$ & Kavitha et al., 2017 \\
\hline 5. & Magnesium sulfate-mediated bacterial pre-treatment & $21 \%$ & $19.2 \%$ & Ushani et al., 2017 \\
\hline 6. & Sodium thiosulphate-mediated bacterial pre-treatment & $22 \%$ & $19.1 \%$ & Ushani et al., 2018 \\
\hline 7. & Ultrasonically mediated bacterial pre-treatment & $20.3 \%$ & $17.1 \%$ & Kavitha et al., 2019b \\
\hline 8. & Disperser-mediated bacterial pre-treatment & $23.9 \%$ & $19.1 \%$ & This study \\
\hline
\end{tabular}


reduction in suspended solids and the enhancement in COD solubilization were used to measure the process efficiency (Kavitha et al., 2014b).

\section{Reduction of Suspended Solids}

The efficiency of bacterially mediated disintegration on deflocculated and flocculated sludge was assessed by suspended solid disintegration (Ushani et al., 2018). The disparities in SS reduction between sludge samples are shown in Figure 2. According to Figure 2, a notable increase in SS reduction up to $42 \mathrm{~h}$ was observed in all three samples. During biological pre-treatment through the action of exoenzymes, suspended solids (SS) become solubilized, and this leads to a reduction in the concentration of solids in the medium. At $42 \mathrm{~h}$, the SS reductions were observed to be $19.1,8.7$, and $4.1 \%$ for deflocculated, flocculated, and control samples, respectively. Among the samples, deflocculated sludge exhibited a greater SS (19.1\%) reduction when compared to flocculated $(8.7 \%)$ and control (4.1\%) sludge. When SS was solubilized, it became either liquefied or mineralized. Figure 2 shows two phases of SS reduction in all samples (control, flocculated, and deflocculated), which were confirmed through linear regression analysis. Kavitha et al. (2017) noticed a similar pattern of SS reduction during bacterial pre-treatment of WAS. SS reduction was very fast in the first phase (from 0 to $42 \mathrm{~h}$ ), and it slowed down in the second phase $(48-84 \mathrm{~h})$. A student $t$-test was conducted to estimate the correlation coefficient for the two phases, and it was found to be in the range of $0.88-0.92$. This indicates that the model satisfies the experimental outcome, and a $p$-value of 0.028 was found for the SS reduction.

Researchers working on sludge disintegration have stated that liquefaction of suspended solids is one of the principal phenomena responsible for the rise in soluble organics (Ushani et al., 2018). Microbes secrete exoenzymes and liquefy particulate organics. However, under harsh pre-treatment conditions, particulate organics become mineralized by microorganisms. From the above, it is evident that as a result of deflocculation, more particulate organics become accessible to bacterially mediated disintegration. This leads to greater solubilization and reduction of SS into the medium. In a previous study, Packyam et al. (2015) achieved a $17.8 \%$ SS reduction by phase-separated pre-treatment. The presently observed SS reduction of $19.1 \%$ was higher than the earlier observations. It is observed that solid removal stabilizes at $42 \mathrm{~h}$, and further increase over time did not significantly contribute to SS removal efficiency. At $42 \mathrm{~h}$, bacterial treatment becomes saturated and, thereafter, inoculated bacteria exhibit insignificant lytic activity.

\section{Soluble Chemical Oxygen Demand Release}

For efficient anaerobic digestion, the substrate needs to contain a sufficient amount of soluble organics. Hydrolysis is responsible for the formation of soluble organics and is the rate-limiting step of anaerobic digestion. Bacterial pre-treatment enhances hydrolysis of the substrate by accelerating its disintegration

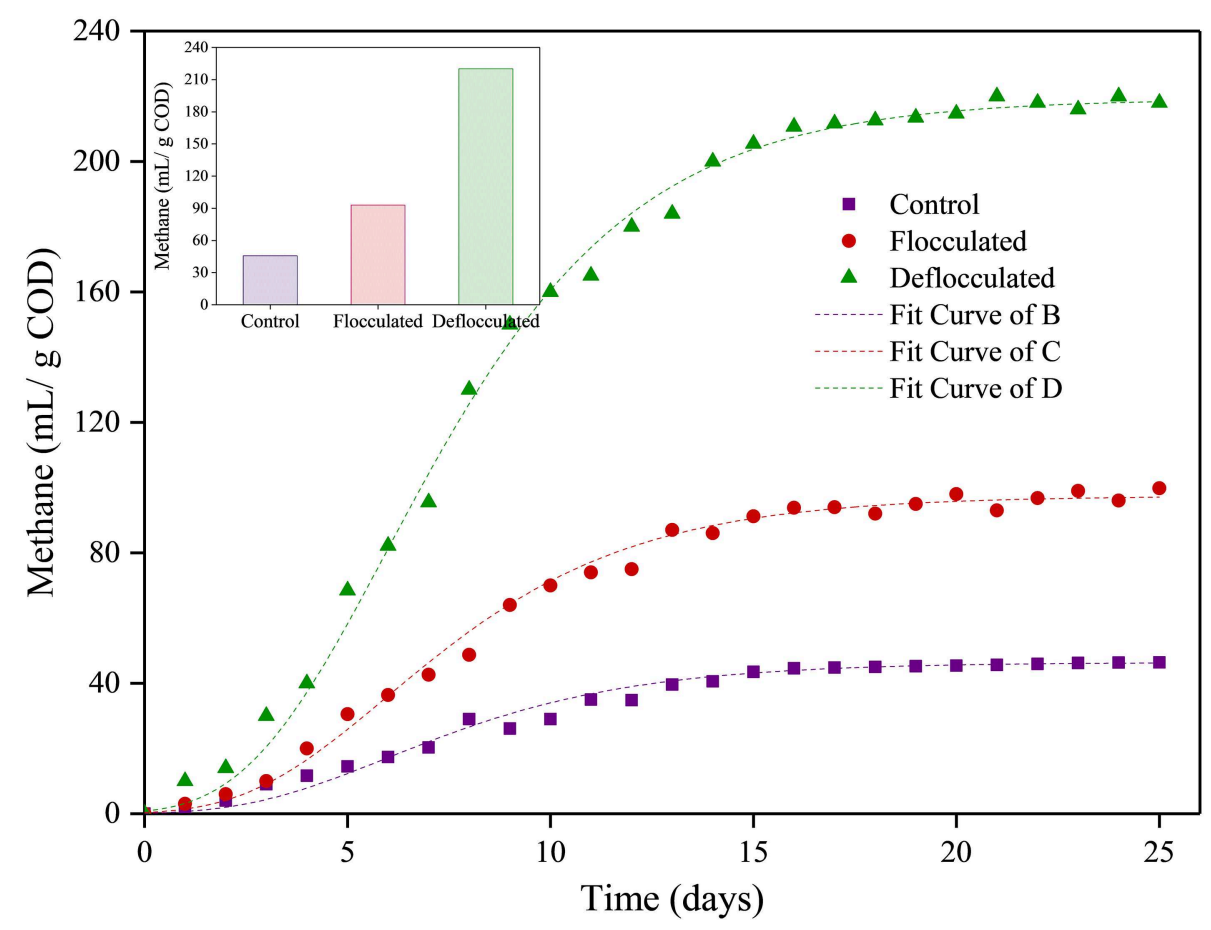

FIGURE 5 | Effect of flocculated and deflocculated sludge on methane production. 
and accumulating soluble organics in the medium. It is essential to obtain a minimum of $20 \%$ solubilization if the disintegrated biomass it to be used for biogas production. Figure 3 shows the effect of bacterial pre-treatment on the profile of soluble organics release with respect to time. The release of SCOD showed an incrementing tendency with time until $42 \mathrm{~h}$, which was expected. After inoculation with bacteria, solubilization was evidenced in all samples by $6 \mathrm{~h}$. From then onward, increment in COD solubilization occurred, lasting to $42 \mathrm{~h}$. During this time interval, the increment for the control was from 0.7 to $5.2 \%$, that for flocculated was from 1.5 to $10.9 \%$, and that for deflocculated was from 3.3 to $23.9 \%$. The maximum release of organics occurred at $42 \mathrm{~h}$. The SCOD of control, flocculated, and deflocculated sludge at $42 \mathrm{~h}$ was found to be 624,784 , and $1,750 \mathrm{mg} / \mathrm{L}$, respectively. According to Kavitha et al. (2017), for economically efficient biofuel production, pre-treatment should yield a minimum of $20 \%$ COD solubilization. In the present study, deflocculation enhanced the efficiency of bacterial pre-treatment. As a result, COD solubilization in excess of $20 \%$ was achieved in this study, whereas the rest of the experiments failed to induce the landmark COD solubilization of $20 \%$. After $42 \mathrm{~h}$, a decrement in the release of organics and COD solubilization was observed in all samples. Table 2 shows a comparison of COD solubilization and SS reduction with the various phase-separated bacterial pre-treatments.

\section{Biopolymer Release}

The concentration contours of biopolymer release are shown in Figure 4. Protein and carbohydrate were found in the intracellular region of the activated sludge biomass. Disintegration induces the release of these biopolymers from inside the cell to the surroundings (Ushani et al., 2017). It was expected that the release of protein and carbohydrate from the biomass would improve with an increase in bacterial pretreatment time. As expected, a gradual increase in biopolymer concentration with respect to bacterial pre-treatment time was noticed in the present study. Depending on the pre-treatment time, the release of biopolymers exhibited two phases: that up to $42 \mathrm{~h}$ is the solubilization phase, and that after $42 \mathrm{~h}$ is the mineralization phase. Similar to SS reduction, a meager amount of biopolymers were released from the control sludge. At $42 \mathrm{~h}$, the protein and carbohydrate releases were found to be 187 and $396 \mathrm{mg} / \mathrm{L}$ for the control, 374 and $784 \mathrm{mg} / \mathrm{L}$ for flocculated, and 860 and $1,720 \mathrm{mg} / \mathrm{L}$ for deflocculated, respectively. A decrease in biopolymer concentration was noticed after $42 \mathrm{~h}$ of pre-treatment. After $42 \mathrm{~h}$, the liquefied carbohydrates and proteins started to be converted into simple components by the action of enzymes (Jang et al., 2014). As a result, a decrease in biopolymer concentration occurred. The protein and carbohydrate concentrations after $42 \mathrm{~h}$ were found to be 1,530 and $762 \mathrm{mg} / \mathrm{L}$, respectively. Overall, deflocculated sludge has a higher potential to release protein and carbohydrate than control and flocculated sludge. Based on the above, the optimal pre-treatment time for sludge disintegration was fixed at $42 \mathrm{~h}$.

\section{BMP Assay}

Finally, BMP tests were carried out to determine the effect of deflocculation on biomethane production. In the literature, several researchers have employed BMP to study the effect of phase-separated pre-treatment on biogas production (Kannah et al., 2017b; Banu et al., 2018; Kavitha et al., 2018). Figure 5 denotes sluggish production of biogas at the start and end of the experiment. The initial sluggishness was due to acclimatization and proliferation of methanogens to new environmental conditions (De Gioannis et al., 2009). At the end of the experiment, the availability of substrate for microorganisms was limited, and this led to poor gas production. The Gompertz equation was used to evaluate the methane generation by fitting the observed data (Gil et al., 2011) and was used to calculate the kinetic parameters of substrate methane generation potential (Uma Rani et al., 2014). Figure 5 depicts data on daily biogas production. In the present study, the biogas profile of all of the samples exhibits lag, exponential, and stationary phases. Upto day 4, biogas production was marginal in all samples subjected to BMP. After the fourth day, the methane generation was amplified from 31 to $43 \mathrm{~mL} / \mathrm{gCOD}$ for flocculated sludge and from 69 to $96 \mathrm{~mL} / \mathrm{gCOD}$ for deflocculated sludge, and this exponential increase lasted up to 7 days. This indicates a shift of phase from lag to exponential, and as a result, more biogas production was achieved (Kannah et al., 2017b; Banu et al., 2018; Kavitha et al., 2018). Certainly, a higher yield of methane was recorded from the deflocculated sample. However, the yield of methane from the control (raw sludge) was comparatively lower $(15-20 \mathrm{~mL} / \mathrm{gCOD})$ than from the flocculated and deflocculated sludge. This is because the control sample (raw sludge) consisted of refractory components, which resist anaerobic degradation during BMP assay. As a result, very low biogas production was recorded in the control. The production of methane reaches saturation due to non-availability of utilizable substrate, and this happens after 15 days of digestion. During this period, methanogenic microbes face limited substrate availability. This is the primary reason for the very low biogas release. On the twenty-first day, deflocculated sludge yielded $220 \mathrm{~mL} / \mathrm{gCOD}$ of biogas. At the same time point, the biogas productions of the control and flocculated sludge were found to be 46 and $96 \mathrm{~mL} / \mathrm{g}$ COD, respectively. From the above, it was evident that deflocculation effectively enhanced hydrolysis and that this resulted in the maximum biogas production when compared to flocculated sludge and control.

Even though biological pre-treatment has many promising features, a major impediment to employing biological agents for bioenergy production is its poor solubilizing potential. However, the outcome of this study provides new scope for biological pre-treatment methods, as it effectively increased this solubilizing potential. Energy and economic analysis have shown that $20 \%$ solubilization is essential for cost-effective biogas production. Apart from the present study, only a few studies in the literature have reported the achievement of the landmark 20\% solubilization. Another advantage of biological pre-treatment is that it demands less energy than do other pre-treatment methods. Based on the above facts, it 
is important to determine whether the results of the present study are scalable. Further study at a pilot-scale level is essential for energy and cost analysis. Work in this regard is in progress.

\section{CONCLUSION}

The use of a disperser effectively removed EPS from waste activated sludge and disrupted its floc structure. Disperser operation at 3,000 rpm for a time duration $50 \mathrm{~s}$ resulted in deflocculation of WAS. A sharp increase in DNA concentration indicated phase separation in disperser operation. Enzymesecreting Bacillus lichiniformis was used as a biological agent to disintegrate the sludge. Deflocculation effectively increased the solubilization of WAS, and at $42 \mathrm{~h}$, a COD solubilization of $23 \%$ was achieved. The results from BMP clearly indicate the supremacy of deflocculation over control for the production of biogas. Biogas production

\section{REFERENCES}

APHA (2005). Standard Methods for the Examination of Water and Wastewater, 21st Edn. Washington, DC: American Public Health Association.

Banu, J. R., Do Khac, U., Kumar, S. A., Ick-Tae, Y., and Kaliappan, S. (2012). A novel method of sludge pretreatment using the combination of alkalis. J. Environ. Biol. 33, 249-253.

Banu, J. R., Kannah, R. Y., Kavitha, S., Gunasekaran, M., and Kumar, G. (2018). Novel insights into scalability of biosurfactant combined microwave disintegration of sludge at alkali $\mathrm{pH}$ for achieving profitable bioenergy recovery and net profit. Bioresour. Technol. 267, 281-290. doi: 10.1016/j.biortech.2018.07.046

Banu, J. R., and Kavitha, S. (2017). "various sludge pretreatments: their impact on biogas generation BT," in Waste Biomass Management-A Holistic Approach, eds L. Singh, and V. C. Kalia (Cham: Springer International Publishing), 39-71. doi: 10.1007/978-3-319-49595-8_3

Banu, J. R., Parvathy Eswari, A., Kavitha, S., Kannah, R. Y., Kumar, G., Jamal, M. T., et al. (2019b). Energetically efficient microwave disintegration of waste activated sludge for biofuel production by zeolite: Quantification of energy and biodegradability modelling. Int. J. Hydrogen. Energy 44, 2274-2288. doi: 10.1016/j.ijhydene.2018.06.040

Banu, J. R., Ushani, U., and Kannah, R. Y. (2017). "Activated sludge process and energy BT"'in Optimization and Applicability of Bioprocesses, eds H. J. Purohit, V. C. Kalia, A. N. Vaidya, and A. A. Khardenavis (Singapore: Springer Singapore), 187-210. doi: 10.1007/978-981-10-6863-8_9

Banu, R., Kumar, D., Eswari, P., Kumar, A., and Park, J. -H. (2019a). Biohydrogen generation from macroalgal biomass, Chaetomorpha antennina through surfactant aided microwave disintegration. Front. Energy Res. 7:78. doi: $10.3389 /$ fenrg. 2019.00078

De Gioannis, G., Muntoni, A., Cappai, G., and Milia, S. (2009). Landfill gas generation after mechanical biological treatment of municipal solid waste. Estimation of gas generation rate constants. Waste Manag. 29, 1026-1034. doi: 10.1016/j.wasman.2008.08.016

Devi, T., Vimala Ebenezer, A., Adish Kumar, S., Kaliappan, S., and Banu, J. R. (2014). Effect of deflocculation on the efficiency of disperser induced dairy waste activated sludge disintegration and treatment cost. Bioresour. Technol. 167, 151-158. doi: 10.1016/j.biortech.2014.06.004

Ebenezer, A. V., Arulazhagan, P., Kumar, S. A., Yeom, I.-T., and Banu, J. R. (2015). Effect of deflocculation on the efficiency of low-energy microwave pretreatment and anaerobic biodegradation of waste activated sludge. Appl. Energy 145, 104-110. doi: 10.1016/j.apenergy.2015. 01.133 in deflocculated waste activated sludge was found to be $220 \mathrm{~mL} / \mathrm{gCOD}$.

\section{DATA AVAILABILITY STATEMENT}

The datasets generated for this study are available on request to the corresponding author.

\section{AUTHOR CONTRIBUTIONS}

DR carried out the work. JB helped in manuscript preparation. RK helped in data processing. DN, GK, and SC have reviewed the manuscript. SR supervised the work.

\section{ACKNOWLEDGMENTS}

This work was supported in part by the Korea Institute of Energy Technology Evaluation and Planning (KETEP) and the Ministry of Trade, Industry \& Energy (MOTIE) of the Republic of Korea (No. 20194110300040).

Gayathri, T., Kavitha, S., Kumar, S. A., Kaliappan, S., Yeom, I. T., and Banu, J. R. (2015). Effect of citric acid induced deflocculation on the ultrasonic pretreatment efficiency of dairy waste activated sludge. Ultrason. Sonochem. 22, 333-340. doi: 10.1016/j.ultsonch.2014.07.017

Gil, M. M., Miller, F. A., Brandão, T. R. S., and Silva, C. L. M. (2011). On the use of the Gompertz model to predict microbial thermal inactivation under isothermal and non-isothermal conditions. Food Eng. Rev. 3, 17-25. doi: 10.1007/s12393-010-9032-2

Jang, H. M., Cho, H. U., Park, S. K., Ha, J. H., and Park, J. M. (2014). Influence of thermophilic aerobic digestion as a sludge pre-treatment and solids retention time of mesophilic anaerobic digestion on the methane production, sludge digestion and microbial communities in a sequential digestion process. Water Res. 48, 1-14. doi: 10.1016/j.watres.2013.06.041

Jang, J.-H., and Ahn, J.-H. (2013). Effect of microwave pretreatment in presence of $\mathrm{NaOH}$ on mesophilic anaerobic digestion of thickened waste activated sludge. Bioresour. Technol. 131, 437-442. doi: 10.1016/j.biortech.2012. 09.057

Jeong, S. Y., Chang, S. W., Ngo, H. H., Guo, W., Nghiem, L. D., Banu, J. R., et al. (2019). Influence of thermal hydrolysis pre-treatment on physicochemical properties and anaerobic biodegradability of waste activated sludge with different solids content. Waste Manag. 85, 214-221. doi: 10.1016/j.wasman.2018.12.026

Kannah, R. Y., Gunasekaran, M., Kumar, G., Ushani, U., Do, K. U., and Banu, J. R. (2019b). "Recent developments in biological nutrient removal," in Water and Wastewater Treatment Technologies, eds B. Xuan Thanh, C. Chiemchaisri, T. Fujioka, and S. Varjan (Singapore: Springer), 211-236. doi: 10.1007/978-981-13-3259-3_11

Kannah, R. Y., Kavitha, S., Banu, J. R., Parthiba Karthikeyan, O., and Sivashanmugham, P. (2017b). Dispersion induced ozone pretreatment of waste activated biosolids: arriving biomethanation modelling parameters, energetic and cost assessment. Bioresour. Technol. 244, 679-687. doi: 10.1016/j.biortech.2017.08.001

Kannah, R. Y., Kavitha, S., Banu, J. R., Yeom, I. T., and Johnson, M. (2017a). Synergetic effect of combined pretreatment for energy efficient biogas generation. Bioresour. Technol. 232, 235-246. doi: 10.1016/j.biortech.2017.02.042

Kannah, Y., Banu, J. R., Joe, J. M., Yeom, I. T., and Do, K. U. (2019a). Profitable sludge management via novel combined ozone disperser pretreatment coupled with membrane bioreactor for treating confectionary wastewater. J. Clean. Product. 239:118102. doi: 10.1016/j.jclepro.2019.118102

Kavitha, S., Adish Kumar, S., Yogalakshmi, K. N., Kaliappan, S., and Banu, J. R. (2013). Effect of enzyme secreting bacterial pretreatment on enhancement of 
aerobic digestion potential of waste activated sludge interceded through EDTA. Bioresour. Technol. 150, 210-219. doi: 10.1016/j.biortech.2013.10.021

Kavitha, S., Banu, J. R., Kumar, G., Kaliappan, S., and Yeom, I. T. (2018). Profitable ultrasonic assisted microwave disintegration of sludge biomass: Modelling of biomethanation and energy parameter analysis. Bioresour. Technol. 254, 203-213. doi: 10.1016/j.biortech.2018.01.072

Kavitha, S., Banu, J. R., Vinoth Kumar, J., and Rajkumar, M. (2016a). Improving the biogas production performance of municipal waste activated sludge via disperser induced microwave disintegration. Bioresour. Technol. 217, 21-27. doi: 10.1016/j.biortech.2016.02.034

Kavitha, S., Devi, T. P., Kannah, R. Y., Kaliappan, S., and Banu, J. R. (2019a). "Post-treatment methods for organic solid wastes," in Post Treatments of Anaerobically Treated Effluents, eds V.K. Tyagi, A. A. Khan, A. Khursheed, A. A. Kazmi, N. G. Jern. doi: 10.2166/9781780409740_0323

Kavitha, S., Jayashree, C., Adish Kumar, S., Yeom, I. T., and Banu, J. R. (2014b). The enhancement of anaerobic biodegradability of waste activated sludge by surfactant mediated biological pretreatment. Bioresour. Technol. 168, 159-166. doi: 10.1016/j.biortech.2014.01.118

Kavitha, S., Jayashree, C., Kumar, S. A., Kaliappan, S., and Banu, J. R. (2014a). Enhancing the functional and economical efficiency of a novel combined thermo chemical disperser disintegration of waste activated sludge for biogas production. Bioresour. Technol. 173, 32-41. doi: 10.1016/j.biortech.2014.09.078

Kavitha, S., Kannah, R. Y., Gunasekaran, M., Nguyen, D. D., Al-Muhtaseb, A. H., Park, J.-H., et al. (2019b). Effect of low intensity sonic mediated fragmentation of anaerobic granules on biosurfactant secreting bacterial pretreatment: energy and mass balance analysis. Bioresour. Technol. 279, 156-165. doi: 10.1016/j.biortech.2019.01.118

Kavitha, S., Kannah, R. Y., Yeom, I. T., Do, K.-U., and Banu, J. R. (2015b). Combined thermo-chemo-sonic disintegration of waste activated sludge for biogas production. Bioresour. Technol. 197, 383-392. doi: 10.1016/j.biortech.2015.08.131

Kavitha, S., Kumar, S. A., Kaliappan, S., Yeom, I. T., and Banu, J. R. (2015a). Achieving profitable biological sludge disintegration through phase separation and predicting its anaerobic biodegradability by non linear regression model. Chem. Eng. J. 279, 478-487. doi: 10.1016/j.cej.2015.05.051

Kavitha, S., Pray, S. S., Yogalakshmi, K. N., Kumar, S. A., and Yeom, I.-T. (2016b). Effect of chemo-mechanical disintegration on sludge anaerobic digestion for enhanced biogas production. Environ. Sci. Pollut. Res. 23, 2402-2414. doi: $10.1007 / \mathrm{s} 11356-015-5461-\mathrm{z}$

Kavitha, S., Preethi, J., Rajesh Banu, J., and Yeom, I. T. (2017). Low temperature thermochemical mediated energy and economically efficient biological disintegration of sludge: simulation and prediction studies for anaerobic biodegradation. Chem. Eng. J. 317, 481-492. doi: 10.1016/j.cej.2017.02.092

Kavitha, S., Saranya, T., Kaliappan, S., Kumar, S. A., Yeom, I.T. and Banu, J. R. (2015c). Accelerating the sludge disintegration potential of a novel bacterial strain Planococcus jake 01 by $\mathrm{CaCl}_{2}$ induced deflocculation. Bioresour. Technol. 175, 396-405. doi: 10.1016/j.biortech.2014.10.122

Merrylin, J., Kaliappan, S., Adish Kumar, S., Yeom, I. T., and Rajesh, B. J. (2013). Effect of extracellular polymeric substances on sludge reduction potential of Bacillus licheniformis. Int. J. Environ. Sci. Technol. 10, 85-92. doi: $10.1007 /$ s13762-012-0141-8
Packyam, G. S., Kavitha, S., Adish Kumar, S., Kaliappan, S., Yeom, I. T., and Banu, J. R. (2015). Effect of sonically induced deflocculation on the efficiency of ozone mediated partial sludge disintegration for improved production of biogas. Ultrason. Sonochem. 26, 241-248. doi: 10.1016/j.ultsonch.2015. 01.015

Saha, M., Eskicioglu, C., and Marin, J. (2011). Microwave, ultrasonic and chemo-mechanical pretreatments for enhancing methane potential of pulp mill wastewater treatment sludge. Bioresour. Technol. 102, 7815-7826. doi: 10.1016/j.biortech.2011.06.053

Sharmila, V. G., Kavitha, S., Rajashankar, K., Yeom, I. T., and Banu, J. R. (2015). Effects of titanium dioxide mediated dairy waste activated sludge deflocculation on the efficiency of bacterial disintegration and cost of sludge management. Bioresour. Technol. 197, 64-71. doi: 10.1016/j.biortech.2015. 08.038

Takahashi, E., Ledauphin, J., Goux, D., and Orvain, F. (2010). Optimising extraction of extracellular polymeric substances (EPS) from benthic diatoms: comparison of the efficiency of six EPS extraction methods. Mar. Freshw. Res. 60, 1201-1210. doi: 10.1071/MF08258

Uma Rani, R., Adish Kumar, S., Kaliappan, S., Yeom, I.-T., and Banu, J. R. (2014). Enhancing the anaerobic digestion potential of dairy waste activated sludge by two step sono-alkalization pretreatment. Ultrason. Sonochem. 21, 1065-1074. doi: 10.1016/j.ultsonch.2013.11.007

Ushani, U., Banu, J. R., Kavitha, S., Kaliappan, S., and Yeom, I. T. (2017). Immobilized and MgSO4 induced cost effective bacterial disintegration of waste activated sludge for effective anaerobic digestion. Chemosphere 175, 66-75. doi: 10.1016/j.chemosphere.2017. 02.046

Ushani, U., Kavitha, S., Kannah, R. Y., Gunasekaran, M., Kumar, G., Nguyen, D. D., et al. (2018). Sodium thiosulphate induced immobilized bacterial disintegration of sludge: an energy efficient and cost effective platform for sludge management and biomethanation. Bioresour. Technol. 260, 273-282. doi: 10.1016/j.biortech.2018.03.118

Yang, L. M., Shu, C., Wu, J., Zhao, N., and Lu, Z. L. (2013). Circular function-based gas-kinetic scheme for simulation of inviscid compressible flows. J. Comput. Phys. 255, 540-557. doi: 10.1016/j.jcp.2013. 08.025

Yu, Q., Lei, H., Li, Z., Li, H., Chen, K., Zhang, X., et al. (2010). Physical and chemical properties of waste-activated sludge after microwave treatment. Water Res. 44, 2841-2849. doi: 10.1016/j.watres.2009.11.057

Conflict of Interest: The authors declare that the research was conducted in the absence of any commercial or financial relationships that could be construed as a potential conflict of interest.

Copyright (C) 2019 Rufus, Banu, Kannah, Nguyen, Kumar, Chang and Raja. This is an open-access article distributed under the terms of the Creative Commons Attribution License (CC BY). The use, distribution or reproduction in other forums is permitted, provided the original author(s) and the copyright owner(s) are credited and that the original publication in this journal is cited, in accordance with accepted academic practice. No use, distribution or reproduction is permitted which does not comply with these terms. 